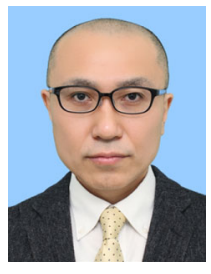

吉田隆弘 (正員)

1996 武蔵工大·工·経営工卒. 1998 同大学 大学院修士課程了. 早大 · 理工学研究科・博士後期 課程入学. 2000 同大学助手. 2007 中央大専任 研究員, 2010 青学大助手, 2013 横浜商科大専 任講師, 2016 同大学准教授, 現在に至る. 博士 (工学)。情報理論とその応用に関する研究に従事. 2016 -2017情報理論研究専門委員会幹事, 2018 同委員会幹事補佐.

\title{
口信号処理研究会 (SIP)
}

信号処理研究会 $(S I P)$ は, 年 5 回行う研究会を中心にソサイエティ大会, 総合大会, 信号処理シンポジウムを主な活動の場 としています. SIP 研究会では, 数理最適化や機械学習などの基礎理論から，画像，映像，音声，音響通信，生体信号などの応 用分野に至る幅広しテーマを扱っており，非常に活発な議論が展開されています。

近年, SIP 研究会で発表した発表者の中から優秀な発表を研究会賞として表彰しています. 対象者に制限がありませんので, どなたでもSIP 研究会で発表し，賞を目指すことができます，

2019 年度の研究会, シンポジウムの開催予定は, 以下のとおりです.

2019 年 5 月 23〜24日 2019 年 7 月 $30 \sim 31$ 日 2019 年 8 月 29 30日 2019 年 11 月 13〜 15 日 2020 年 1 月 23 日 24日 2020 年 3 月

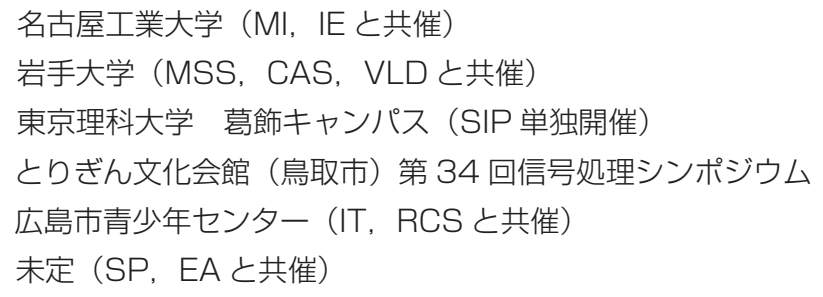

特に信号処理シンポジウムは, 日本中の信号処理研究者が集う大型イベントとなっており, この分野の進展と研究動向を知る上 で, 重要なイベントとなっています，また，このシンポジウムでは，招待講演，企業ワークショップ，企画セッション，IEEE Distinguished Lecture 等も例年開催されております。このシンポジウムでは, 口頭発表（予稿原稿 4 から 6 ページ : 主にフ ルペーパー）とポスター発表（予稿原稿 1〜2ページ：主にショートペーパー）があり, 多様な形式で研究発表ができるように なっております．また，優れたフルペーパー発表には信号処理若手奨励賞が授与されます．

是非 SIP 研究会，信号処理シンポジウムへ御投稿・御参加頂き，活発な議論をして頂きますようお願し致します．数多くの皆 様の御参加をお待ちしております.

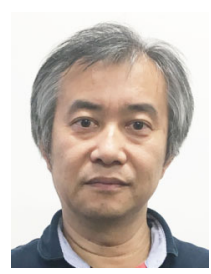

相川直幸 (正員)

1985 山梨大·工·電気卒, 1987 都立大大学 院工学研究科博士前期課程了·博士（工学, 1992 都立大)。都立大·工・助手、東京工科大，日大を経 て, 現在，東京理科大·基礎工・教授，信号処理に 関する研究に従事。

\section{ロワイドバンドシステム研究会 (WBS)}

ワイドバンドシステム研究会はスペクトル拡散技術や OFDM (Orthogonal Frequency Division Multiplex), UWB (UltraWideband）などの広帯域通信方式，広帯域を用いるセンシング技術並びに光無線通信システムなどの基礎・基盤となる技術に ついて理論的な側面や応用まで幅広く取り扱っており，当分野の研究者や技術者との交流を促進し，その発展に寄与することを目 的に活動を行っております，広帯域技術及びその応用分野は多岐に渡っており，関連する分野との連携を深めるため，衛星通信研 究会 (SAT), 高信頼制御通信研究会 (RCC), 高度交通システム研究会 (ITS), 情報理論研究会 (IT), 情報セキュリティ研究 会 (ISEC) 及びヘルスケア・医療情報通信技術研究会 (MICT) の各研究会と共催企画を行っております. 現在は, 年 5 回の研 究会を開催しております

最近の活動状況は以下のとおりです.

2018 年 5 月は鹿児島大学において, SAT 研究会と併催し, 広帯域符号化・変復調に関する検討や無人航空機（UAV: Un- 
manned aerial vehicle）に関する講演を含め, 16 件の講演がありました．７月はMICT 研究会と共催により横浜で開催されま した. 7 月の研究会では 7 件のポスタ一講演及び 6 件の口頭講演があり, 光無線通信や広帯域通信に関する講演及び災害時のセ ンシングに関する講演がありました. 10 月は, 広島商船高等専門学校において開催しました. ここでは, 特に, 可視光光無線通 信に関する講演を中心に 9 件の口頭発表がありました. 12 月は, ITS 研究会およびRCC 研究会との共催により, 宮古島で研究 会を開催しました. 27 件のポスタ一講演を含み全部で 49 件の講演がありました. 今回は, 一般講演に加えて, 「UWB 無線の これまでとこれから」と題し企画セッションを行い, 日本の UWB 研究開発の第一人者である東京電機大学の小林岳彦先生, NICT の李還幇様, 並びに, 富士ロジテックホールディングスの川公義様から UWB の研究開発動向及び成果について報告があ りました.

2019 年 3 月は電気通信大学において ISEC 研究会，IT研究会との共催により開催されました. 52 件の発表があり，特に理 論的な側面からの数多くの講演がありました. 2019 年 5 月は, 再びSAT 研究会との併催で名城大学において開催され, 16 件の講演がありました.

今後，7月茨城大学において MICT 研究会との共催により研究会を開催予定です。これに関連して，12月7-8 日には，ミャ ンマーの Yangon Technological University において International Workshop on Control, Communication, and Multimedia が開催されます.

今後の「ソサイエティ 5.0 」を支える基盤技術として超広帯域無線ネットワークとセンサ技術の進展が不可欠です. 本研究会 では，これらの基盤技術及びその応用事例として自動運転，UAV といった応用技術について研究者との交流を通じて発展に寄与 できる場を提供できればと考えております。是非, ワイドバンドシステム研究会に御参加下さい.

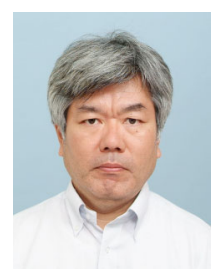

岡田 実 (正員)

1992 阪大大学院工学研究科通信工学専攻修士 了. 1993 阪大工学部助手. 1999 Southampton University 客員研究員. 2000 奈良先端大助 教授. 2006 同教授. 博士 (工学) (大阪大学)。移 動通信, 地上デジタルテレビ放送, 衛星通信の変復 調に関する研究に従事. また, RFID, ワイヤレス電 力伝送に関する研究に従事. 映像情報メディア学会, 日本コンピュー夕外科学会, IEEE 各会員.

\section{高信頼制御通信研究会（RCC）}

高信頼制御通信研究会（RCC : Reliable Communication and Control）は, ロボット制御通信やプラント内通信などの高い 信頼性が求められる通信にフォーカスし，その基礎理論から応用技術までを幅広くカバーする研究会です.

制御通信の分野はロボット社会の到来とともに研究開発が活発化しており，当研究会では産業界の方の参加をより一層促すた め, 毎年 1 月の研究会で「イブニング・セッション」を開催しています.「イブニング・セッション」では第一線で活躍する研究 者を講師として招待し, 約 3 時間たつぷりと講義を開いています。平成 30 年 1 月は京都大学西尾先生をお招きして「機械学習 の基礎と無線通信制御への応用, 平成 31 年 1 月は名古屋工業大学和田山先生をお招きして「無線物理層におけるデー夕駆動ア プローチ 深層学習への期待と展望」という題目で御講演頂きました. 企業の方にも参加しやすいよう, 都心エリアで夕方からの 開催としています，毎年多くの方に御参加頂き，好評頂しております．

また，毎年 5 月の研究会はWTP（ワイヤレス・テクノロジー・パーク）との同時開催で東京ビッグサイトにて実施しておりま す．最新のワイヤレス技術と制御通信技術に同時に触れ合える絶好の機会ですので，是非御参加下さい．

今年度の研究会等開催予定は以下のとおりです．詳細や最新の情報はRCC のウェブページ（http://www.ieice.org/ rcc/) を御覧下さい.

令和元年

5 月29日〜30日開催 東京ビッグサイト：招待講演，ポスター技術展示（MICT 研究会共催, WTP2019 同時開催)

7月 10 日 12日開催予定 12 月開催予定 Isite (大阪難波)：SeMI, RCS, SR, NS 研究会併催 令和 2 年

1 月開催予定 場所未定：WBS, ITS 研究会との共催 場所未定：単独開催（イブニング・セッションを予定） 